\title{
Intercropping flowering plants in maize systems increases pollinator diversity
}

by Norris, S.L., Blackshaw, R.P., Critchley, C.N.R, Dunn, R.M., Smith, K.E., Williams, J., Randall, N.P. and Murray, P.J.

Copyright, publisher and additional information: This is the author accepted manuscript. The final published version (version of record) is available online via Wiley.

This article may be used for non-commercial purposes in accordance with Wiley Terms and Conditions for Self-Archiving.

DOI: https://doi.org/10.1111/afe.12251

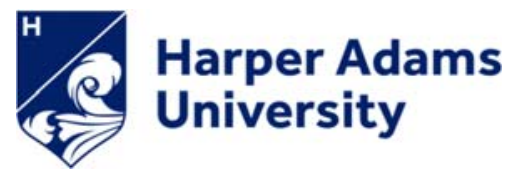

Norris, S.L., Blackshaw, R.P., Critchley, C.N.R, Dunn, R.M., Smith, K.E., Williams, J., Randall, N.P., Murray, P.J. 2017. Intercropping flowering plants in maize systems increases pollinator diversity. Agricultural and Forest Entomology 
1 Title: Intercropping flowering plants in maize systems increases pollinator diversity

2

\section{Authors}

4 Stuart L Norris ${ }^{1,2^{\star}}$, Rod P. Blackshaw ${ }^{2}$, C. Nigel R. Critchley ${ }^{3}$, Robert M. Dunn ${ }^{1}$, Kate

$5 \quad$ E. Smith ${ }^{4}$, John Williams ${ }^{4}$, Nicola P. Randall ${ }^{2}$ and Philip J. Murray ${ }^{1}$

6

$7 \quad{ }^{1}$ Sustainable Soils and Grassland Systems Department, Rothamsted Research,

$8 \quad$ North Wyke, Okehampton, Devon, EX20 2SB, U.K

$9 \quad{ }^{2}$ Harper Adams University, Newport, Shropshire, TF10 8NB, UK

$10{ }^{3}$ ADAS UK Ltd, c/o Newcastle University, NEFG Offices, Nafferton Farm, Stocksfield,

11 Northumberland NE43 7XD, UK

$12{ }^{4}$ ADAS Boxworth, Battlegate Road, Boxworth, Cambridge, CB23 4NN, UK

14 * Corresponding Author

15 Stuart Norris

16 Sustainable Soils and Grassland Systems Department,

17 Rothamsted Research,

18 North Wyke,

19 Okehampton,

20 Devon, EX20 2SB UK.

21 stuart.norris@vixenecology.co.uk 
1. Maize is a poorly competitive crop, as such, soil preparation and high application rates of herbicides are required to reduce early competition with weeds. This leaves a large amount of bare ground with few flowering weeds, providing a poor farmland habitat for pollinators.

2. This study evaluates the effect of four different maize management regimes on pollinator diversity and community composition.

3. Flowering plants intercropped with maize attracted pollinators, helping to support pollinator communities. Similar intercropping techniques using a grass ground cover did not increase pollinator density, demonstrating that pollinator richness, density and diversity is intrinsically linked to the presence of flowering plants.

4. A maize system with a diverse intercrop may make it possible for pollinators to thrive, however, these systems may only be attractive enough to bring pollinators in temporarily from the surrounding areas.

\section{Synthesis}

5. These results show that there can be significant improvements to pollinator diversity, density and community composition through modifying maize cultivation practices, however, these benefits must be balanced with yield penalties of ca. $60 \%$ to farmers.

\section{Keywords}

Agro-ecosystems, bee, community, density, diversity, maize, richness, 


\section{Introduction}

Arable production, especially maize (Zea mays L.), adversely affects pollinator biodiversity (Geiger et al., 2010; Carvell et al., 2011), which is in decline globally (Biesmeijer et al., 2006; Carvell et al., 2011; Goulson, 2015). Whilst there is a need to produce versatile crops, such as maize, to meet agricultural demands (Edgerton, 2009), these must be balanced with protecting ecosystem services, including those that are facilitated by biodiversity (DeFries et al., 2004; Wodika \& Baer, 2015) such as pollination (Delaplane et al., 2000). Pollinator biodiversity depends on four main characteristics of an agro-ecosystem: the diversity of vegetation within and around the system, the permanence of the various crops within the system, the intensity of management, and isolation of the system from natural vegetation (Altieri, 1999; Holzschuh et al., 2007; Batary et al., 2010).

Maize is an increasingly important, multifunctional crop with over 184,000 ha grown annually in the UK (DEFRA, 2015) being used as forage for cattle and is becoming increasingly important as a feed stock for biogas generation (Hochholdinger and Tuberosa, 2009; Adams, 1989; Banse et al., 2008). However, Maize is a poorly competitive crop; therefore intensive soil preparation and high application rates of herbicide are required to reduce early competition with weeds (Hall et al., 1992). This leaves a large amount of bare ground, providing poor habitat for biodiversity, especially for pollinators (Carvell et al., 2011; Hawes et al., 2009; Potts et al., 2006; Barbir et al., 2015). Wilson et al. (1999) identified that these reductions in the diversity and abundance of food plants leads to reduced invertebrate diversity, which is a result of the combination of frequent tillage, improved seed-cleaning technologies and herbicidal weed control. Unfortunately, 
conventional maize cultivation fulfils the criteria set out by Wilson et al. (1999) to erode pollinator biodiversity.

Novel maize cultivation techniques such as sowing the crop into an understorey of legume mixes or grasses have been shown to reduce negative environmental impacts such as nutrient and soil loss by promoting rainfall infiltration, improving soil stability and reducing run-off (Hartwig \& Ammon, 2002; Manevski et al., 2015). These techniques have also been shown to support the farmland biodiversity by providing resources for many species (Pywell et al., 2005; Norris et al., 2016). However, because maize is a poor competitor in its early stages of growth it is easily outcompeted by intercrops. As such, intercrops must be controlled to maintain maize yield (Nakamoto \& Tsukamoto, 2006). Mowing, grazing or spraying with a herbicide have all been shown to maintain crop yield similar to that found in conventional cropping systems, whilst maintaining the above benefits (Nakamoto \& Tsukamoto, 2006). However, contrasting studies have shown that even with control of intercrops by mowing, maize yields can be significantly reduced due to root system competition (Liedgens et al., 2004; Norris et al., 2016).

Supporting pollinator diversity in arable systems is currently a hot topic (Goulson, 2015). Colonisation by invertebrates is generally dependent on natural dispersal from the regional species pool (Chateil, 2015), which can be highly fragmented (Hilderbrand et al., 2005), and where there are greater numbers of flowering plant species there will be greater richness, density and diversity of pollinators. In arable systems, a disturbance such as ploughing or tillage disrupts this colonisation process, and although biotic and abiotic conditions can be restored to these systems, community assemblages sometimes cannot (Hilderbrand et al., 2005). Despite this, recent work by Wodika \& Baer (2015) has shown that this is not 
necessarily the case, even with soil fauna, which have lesser dispersal efficiency compared with pollinators (Giller, 1996). Wodika \& Baer (2015) showed that after disturbance there can be a recolonisation by taxa comprising of a similar community assemblage to the pre-disturbance state, if the vegetative community is restored. Sadly, in conventional maize cultivation systems, there are often few flowering noncrop plants, which limits forage resources for pollinators (Hawes et al., 2009; Potts et al., 2006). As maize is wind pollinated, increasing pollinators in maize systems would not directly benefit the maize crop, however, supporting pollinators at the farm or landscape scale would benfit other crops such as Brassica napus L. as well as wild flora.

In this study, we investigated the effect of four contrasting maize cultivation and ground cover management practices on pollinator density, diversity and community composition and maize yields, to identify sustainable maize production techniques. We hypothesized that where greater numbers of flowering plants were sown in the strip tillage biodiverse seed mix cultivation methods, larger populations of pollinators would be encountered.

\section{Materials and methods}

\subsection{Site description}

Field experiments were established in a conventionally ploughed maize crop at two study sites over two cultivation seasons in April 2013; the first site was in the South West of England near Bow, Devon and the second in the east of the UK, near Fakenham, Norfolk. The study sites were selected for the freely draining, slightly acidic loam soil at Bow and freely draining slightly acid but base-rich soil at Fakenham (Driessen, 2001), which is typical of land under maize cultivation in the 
UK. Maize is often grown in the same field year after year in the UK, as such the intercrops were established in 2013 and the maize in the subsequent two cropping seasons, drilled into the rows that the previous year's crop occupied. Twelve study plots at each site, $10 \mathrm{~m}$ wide and $60 \mathrm{~m}$ in length, with a $1 \mathrm{~m}$ gap between plots, were established in a randomised replicated block design with three replicates of each treatment. Four contrasting maize cultivation techniques were selected to test the effects on pollinator diversity and community structure: 1) conventional plough and subsoiled $(\mathrm{PGH}), 2)$ minimum tillage (MNT), 3) strip tillage into perennial ryegrass that was sown at a rate of $35 \mathrm{~kg} \mathrm{ha}^{-1}$ (RGS) in June 2012, and 4) strip tillage into a biodiverse seed mix (BSM). The BSM strip crop was over sown with a commercially available seed mix in June 2012 at 15 kg/ha ${ }^{-1}$ containing Medicago lupulina L. 20\%, Onobrychis viciifolia L. 25\%, Trifolium hybridum L. 20\% Trifolium incarnatum L. subsp. Incarnatum 20\%, Lotus corniculatus L. 10\%, Malva moschata L. 5\%. For a full experimental design and agronomic details please refer to Norris et al., (2016). At Fakenham in 2013, pre-emergence application of herbicides were 4.5 I ha-1 Stomp® (a.i Pendimethalin) to all treatments; $150 \mathrm{ml}$ ha-1 Reglone ${ }^{\circledR}$ (a.i Diquat) to the two strip tillage treatments and 3.5 I ha-1 of Hoedown ${ }^{\circledR}$ (a.i Glyphosate) was applied to the ryegrass treatment. Post-emergence application of herbicides were 1 I ha-1 Touchdown® (a.i Glyphosate) applied to the ryegrass plots; Callisto ${ }^{\circledR}$ (a.i Mesotrione) at a rate of 1 I ha-1 was applied to PGH and RGS and to the BSM treatment at a rate of 0.5 I ha-1. At Bow in 2013, Pendimethalin (Stomp (C) was applied to all plots except the BSM treatment at application rate of $3.0 \mathrm{I}$ ha- 1 , with an additional 1.0 I ha-1 Samson applied to the perennial ryegrass plots. At Fakenham, in 2014, to reduce intercrop competition and improve yields additional herbicides were applied to the strip-tillage treatments compared with $2013 ; 5$ I ha-1 Wing $P ®$ 
147 (a.i Pendimethalin) was applied to all treatments. Touchdown® at 1 I ha-1 (a.i

148 Glyphosate) was applied to all treatments except BSM where Touchdown® was applied at a half rate of 0.5 I ha- 1 . Post-emergence, Callisto® was applied at a rate of 2 I ha-1 to all treatments. At Bow, in 2014 Gallup® was applied to the BSM treatment at a rate of $1.5 \mathrm{I}$ ha-1, Non-inversion at a rate of $3.0 \mathrm{I}$ ha-1, Conventional at a rate of $3.0 \mathrm{I}$ ha-1 and Ryegrass at a rate of $0.75 \mathrm{I}$ ha-1. After the maize was sown at Devon Wing- $\mathrm{P} \circledast$ was applied at a rate of $4 \mathrm{I}$ ha- 1 with an additional later spraying of Calaris ${ }^{\circledR}$ at $1 \mathrm{I}$ ha- 1 and Samson at $0.5 \mathrm{I}$ ha- 1 to reduce competition from the existing plant cover.

At both sites $150 \mathrm{~kg} \mathrm{~N}$ ha-1 of ammonium nitrate (a.i nitrogen) was applied to all treatments in 2013. At Fakenham in 2014 potash (175 kg ha-1) was applied to all treatments. At Bow in 2014 100kg N ha-1 in the form of Urea and $20 \mathrm{~kg} \mathrm{~N}$ ha-1 in the form of monoammonium phosphate (MAP) was applied to all cultivation methods, and at Norfolk N-fertiliser applications remained the same as in 2013.

\subsection{Pollinator survey}

Pollinators were counted using the line-transect method developed for the UK butterfly-monitoring scheme (Pollard \& Yates, 1993), which has been adapted as a standard method for bee surveys (Roy et al., 2003; Banaszak, 1980). Pollinator transects were walked on a weekly basis during June and July in both field trial years, coinciding with the legume flowering period. Pollinator transects were carried out by walking $60 \mathrm{~m}$ along the intercrop area, but excluding the outermost $1 \mathrm{~m}$ of each plot. Surveyors used transect recording sheets to score the pollinators foraging on each plot. Given the need to identify bees while on the wing, counts were made for groups of bumble-bee (Bombus) species based on colour type, and Apis were 
also noted (Prys-Jones and Corbet, 1991). Walks were performed between 10.00 and 17.30 when weather conformed to UK butterfly monitoring scheme standards (wind speed less than $5.5 \mathrm{~m} \mathrm{~s}^{-1}$, not raining, temperature greater than $17^{\circ} \mathrm{C}$ if sky overcast or greater than $13{ }^{\circ} \mathrm{C}$ if sky at least $60 \%$ clear) (Pollard \& Yates, 1993; Roy et al., 2003). The order in which transects were walked was randomised (Roy et al., 2003; Haughton et al., 2003), using a random number generator. The time taken for each transect depended on crop stage, but observers walked at approximately $12 \mathrm{~m}$ per minute (Banaszak, 1980; Roy et al., 2003;Westphal et al., 2007).

\subsection{Vegetation survey}

Visual assessments of vegetation were carried out in late July in 2013 and 2014. Six vegetation samples were located within the inter-row areas of each plot with a rectangular quadrat $(1.0 \mathrm{~m} \times 0.25 \mathrm{~m})$ placed at different locations, parallel to the rows of maize. Percentage cover by vegetation, litter and bare ground, together with vegetation richness (number of plants $0.25 \mathrm{~m}^{2}$ ) were recorded for each plot. At Fakenham, a conventional maize harvester was used to measure crop yield, with the harvested area of each plot being $7.5 \mathrm{~m} \times \mathrm{c} .60 \mathrm{~m}$. At Bow, maize yields were measured from each plot from a $10 \mathrm{~m}$ by $2 \mathrm{~m}$ area, and each maize plant within the demarcated area was harvested by cutting approximately $15 \mathrm{~cm}$ above the soil surface. Maize plants from both sites were chopped using secateurs before analysis. Harvested samples were oven dried at $60{ }^{\circ} \mathrm{C}$ for 24 hours and the dry weight recorded. Dry weights were multiplied to give a total dry matter per plot and are reported on a tons per hectare basis.

\subsection{Statistical analysis}


All statistical analyses were conducted using R v3.0.1 (R Core Team, 2013). The plant community measurements and total numbers of pollinators observed over six sampling weeks in each sampling year were used to test for differences in richness, density and Shannon diversity using analysis of variance on Box-Cox transformed data (Højsgaard 2006). Density was expressed as the total number of pollinators observed over the six transect walks preformed at each site in 2013 and 2014, with field site being used as a random effect. Once data were normalised, Tukey HSD tests were used to test for significant differences between cultivation methods and field trial years. The diversity for each of the cultivation methods was determined using the Shannon-Weiner diversity index $\left(H^{\prime}\right)$ calculated using the R package 'vegan' (Oksanen et al., 2007; Norris et al., 2016).

Pollinator community counts were Wisconsin square root transformed using Euclidian distances among sites and years to measure species that were associated with changes in vegetation, using two-dimensional non-metric multidimensional scaling (NMDS) which was selected using stress vs. dimensionality to identify the number of axes that best represented the community. The vegetative variables and plant species count data were fitted to the NMDS species scores using the function 'envfit' (Oksanen et al., 2007) based on 999 permutations. Vegetative variates and plant species with a significant influence on pollinator community composition $(P<$ 0.05) were plotted based on the results from 'envfit'. As pollinators were predominantly observed in BSM plots (Table 1), further statistical analysis was performed by separating this cultivation method from the other three cultivation methods and assessing the influence plant species composition had on pollinator communities. 


\section{Results}

The richness, density, and diversity of pollinator communities were significantly greater in the strip tillage into a biodiverse seed mix cultivation method compared to the other three cultivation methods (Table 1). Although some pollinators were encountered in the other cultivation methods, a majority of pollinators were observed in the strip tillage into a biodiverse seed mix cultivation method (Table 2).

In 2014, the increase in herbicide application reduced the richness of vegetation in the biodiverse seed mix cultivation method (Table 1 and Table S1). However, the overall richness, density, and diversity of the pollinator community was not significantly reduced (Table 1 ).

$B$. lapidarius and $B$. terrrestris/lucorum were the most frequently observed, predominately found foraging in the strip tillage into a biodiverse seed mix cultivation method (Table 2). Despite the increased application of herbicides in 2014 , and the subsequent reduction in plant richness (Table 1 ) the number of $B$. hortorum observed increased (Table 2, $P=0.008$ ). However, the abundance of $B$. pascuorum was significantly reduced in $2014(P=0.008)$.

Plant communities were composed of different species in the different treatments $(P<0.001)$, which explained $50 \%$ of the variation (Table 3$)$. Community composition between the two sites was significantly different $(P<0.001)$, although these differences only explained $11 \%$ of the variation in overall pollinator composition (Table 3).

Vegetation richness had a significant influence $(P<0.001)$ on pollinator community composition, explaining $32 \%$ of the overall variation (Table 3 ). Bare ground, negatively correlated with vegetation cover, had a significant influencing 
effect on community composition $(P<0.001)$ explaining $15 \%$ and $26 \%$ of the variation respectively (Table 3).

Separating the BSM pollinator community for more detailed analysis showed that field site and sampling year had a significant effect $(P<0.001)$ on pollinator community composition, which explained $88 \%$ of the variation (Table 3 , Fig. 1).

Vegetation cover also explained a significant $(P=0.044)$ amount of variation $(49 \%)$ in pollinator community composition (Table 3, Fig. 1).

Plant species composition also influenced the composition of pollinators $\left(F^{1,10}\right.$

$254=7.54, P=0.020$, slope = 15.29), Fig 1). The plants that were sown in the BSM

cultivation method established well, however the plant species that influenced

difference in composition between plots and sites were the opportunistic weed species that re-emerged after ploughing (Norris et al., 2016). Urtica urens L. correlated with greater observed numbers of Apis. (Table 6, Fig 1). In contrast,

Epilobium ciliatum Raf., Matricaria recutita L., Senecio vulgaris L. and Trifolium

repens L. were found to be associated with greater observed numbers of $B$.

terrrestris/lucorum and B. pratorum (Fig 1).

Although cultivation year did not significantly effect $(P=0.775)$ community composition (Table 3) when considering both sites and all cultivation methods, there were significant interaction differences in community composition associated with the two sites which changed between the two years in the strip tillage into a biodiverse seed mix cultivation method (Fig. $1, r^{2}=0.88, P=0.001$ ). B.hortorum was associated with Bow in 2014, however, in 2013 the community observed at the Bow site was more associated with greater densities of $B$. terrestris/lucorum (Fig. 1). $B$. pascuorum and B. lapidarius were associated with the Fakenham site in 2014. 
Unlike at Bow, there was no significant difference in community composition between the two years at Fakenham (Fig. 1).

\section{Discussion}

Understanding how to manipulate agrosystems to promote ecosystem services such as pollination is a key goal of agro-ecology (Altieri, 1999). This study has shown that a flowering plant ground cover is important for supporting pollinators. There is strong evidence to suggest that having a number of flowering plants in the biodiverse seed mix ground cover significantly increased the richness, density and diversity of pollinators. (Table 1 and Table S1).

Maize in the UK is often grown year after year in the same field. As such, the experiment mimics conventional practice by performing the field trails for two consecutive years in the same fields using the previous year's maize crops as a guide for where to drill the subsequent crop. Although the maize yield was reduced in the two strip tillage cultivation methods compared with the conventional and minimum tillage cultivation methods (Table 1), in the second year early competition of the intercrops with maize was reduced, increasing maize yields without significantly reducing the richness, density or diversity of pollinators (Table 1). This result confirms that flowering plant availability is a key driver of pollinator abundance and diversity. At the landscape scale, increasing the density of flowering species within arable systems could provide greater resource complexity and stratification to help support pollination and pollinator communities (Roy et al., 2003; Potts et al., 2006).

Separate analysis of the BSM cultivation technique showed that vegetation richness and cover are positively correlated under BSM and vegetation cover was a 
key factor influencing the composition of pollinators utilising these resources (Table 3) suggesting that where there was a greater cover and richness there was greater variety of plant species for pollinators to forage upon.

The separate analysis of the data from the BSM plots (Table 3) showed that the composition of the pollinator community differed between the two sites. Others studies have shown that this may be attributed to natural variation in the surrounding local pollinator populations from which communities were able to recruit (Baur et al., 1996; Tsiafouli et al., 2015). Although not measured in this study, differences between communities over large spatial scales have been shown to be linked to the These results show that it is possible to support greater pollinator populations than are currently supported under conventional maize systems by including only a 
319 flowering plants supported more diverse pollinator communities (Fig 1; Schlinkert et al., 2015).

Although this study shows that it is possible to increase the biodiversity of pollinators in maize systems by increasing the number of flowering plants (Goulson, 2015), these benefits to pollinators must be balanced with the yield penalties to farmers. At both sites, the greatest dry matter yields were measured on the conventional and non-inversion cultivation methods, with a mean dry matter yield of c.11 t/ha. However, yields from the strip tillage-ryegrass (RGS) and strip tillagebiodiverse mix (BSM) were as much as $80 \%$ and $90 \%$ lower than the conventional treatment at Norfolk and Devon respectively (Table 1). Increased herbicide application rate to the intercrop in 2014 reduced early competition with maize and improved yields (Table 1), however, yields on the strip tillage-ryegrass and strip tillage-biodiverse mix were still approximately $45 \%$ lower compared to the conventional treatment. Despite reductions in yield, this study suggests that even a relatively low richness of flowering plants will attract pollinators, supporting populations and the services they facilitate. Despite increases in pollinator richness and diversity a maize system with diverse intercrops may make it possible for pollinators to thrive, however, these systems may only be attractive enough to bring pollinators in temporarily from the surrounding areas.Agricultural schemes to secure proportions of the cultivated area that needs to be sown with flowering plants to support greater numbers of pollinators in arable systems, how this affects pollinator diversity on a landscape scale and the longevity of these effects. 
The work was funded by DEFRA as part of the maize cultivation at reduced

environmental impact project - project number WQ0140. This work was conducted at

Rothamsted Research, a BBSRC funded institute. I would also like to thank Marina

Caron and Amelia Bowden for assisting with pollinator surveys.

\section{References}

Adams, R.M., 1989. Global climate change and agriculture: an economic perspective. American Journal of Agricultural Economics 71, 1272-1279.

Altieri, M.A. (1999) The ecological role of biodiversity in agroecosystems. Agriculture, Ecosystems \& Environment 74, 19-31.

Banaszak, J. (1980) Studies on methods of censusing the numbers of bees (Hymenoptera, Apoidea). Polish Ecological Studies 6, 355-366.

Banse, M., Van Meijl, H., Tabeau, A., Woltjer, G., 2008. Will EU biofuel policies affect global agricultural markets? European Review of Agricultural Economics 35, 117-141.

Barbir, J., Badenes-Pérez, F.R., Fernández-Quintanilla, C., Dorado, J., 2015. Can floral field margins improve pollination and seed production in coriander Coriandrum sativumL. (Apiaceae)? Agricultural and Forest Entomology 17, 302-308

Batary, P., Baldi, A., Sarospataki, M., Kohler, F., Verhulst, J., Knop, E., Herzog, F., Kleijn, D. (2010) Effect of conservation management on bees and insect-pollinated grassland plant communities in three European countries. Agriculture, Ecosystems \& Environment 136, 35-39.

Baur, B., Joschi, J., Schmid, B., Hänggi, A., Borcard, D., Stary, J., Pedroli-Christen, A., Thommen, G.H., Luka, H., Rusterholz, H.-P., 1996. Variation in species 
richness of plants and diverse groups of invertebrates in three calcareous grasslands of the Swiss Jura mountains. Revue suisse de Zoologie 103, 801-833.

Biesmeijer, J.C., Roberts, S., Reemer, M., Ohlemüller, R., Edwards, M., Peeters, T.,

372 Schaffers, A., Potts, S., Kleukers, R., Thomas, C., 2006. Parallel declines in

373 pollinators and insect-pollinated plants in Britain and the Netherlands. Science 313,

$374 \quad 351-354$.

375 Carvell, C., J. L. Osborne, A. F. G. Bourke, S. N. Freeman, R. F. Pywell, and Heard, M. S. (2011) Bumble bee species' responses to a targeted conservation measure depend on landscape context and habitat quality. Ecological Applications 21:17601771.

Chateil, C., Porcher, E. (2015) Landscape features are a better correlate of wild plant pollination than agricultural practices in an intensive cropping system. Agriculture, Ecosystems \& Environment 201, 51-57.

DeFries, R.S., Foley, J.A., Asner, G.P. (2004) Land-use choices: balancing human needs and ecosystem function. Frontiers in Ecology and the Environment 2, 249257.

DEFRA, 20154. Farming Statistics Provisional crop areas, yields and livestock populations. Accessed 06/08/2015; https://www.gov.uk/government/uploads/system/uploads/attachment_data/file/3641 57/structure-jun2013prov-UK-16oct14.pdf

Delaplane, K. S., Mayer, D. D. R., and Mayer, D. F. (2000) Crop pollination by bees. New York: CABI Publishing. 344 p.

Driessen, P.M. 2001. Lecture notes on the major soils of the world. Food and Agriculture Organization of the United Nations. FAO-ISRIC-University WageningenKatolieke Universiteit Leuven 
394 Edgerton, M.D. 2009. Increasing crop productivity to meet global needs for feed, 395 food, and fuel. Plant Physiology 149, 7-13.

396 Geiger, F., Bengtsson, J., Berendse, F., Weisser, W.W., Emmerson, M., Morales, 397 M.B., Ceryngier, P., Liira, J., Tscharntke, T., Winqvist, C., Eggers, S., Bommarco, 398 R., Pärt, T., Bretagnolle, V., Plantegenest, M., Clement, L.W., Dennis, C., Palmer, C., Oñate, J.J., Guerrero, I., Hawro, V., Aavik, T., Thies, C., Flohre, A., Hänke, S., 400 Fischer, C., Goedhart, P.W., Inchausti, P. (2010) Persistent negative effects of 401 pesticides on biodiversity and biological control potential on European farmland. Basic Applied Ecology 11, 97-105.

403 Giller, P.S., 1996. The diversity of soil communities, the 'poor man's tropical 404 rainforest'. Biodiversity \& Conservation 5, 135-168.

Goulson, D. (2015) Neonicotinoids impact bumblebee colony fitness in the field; a reanalysis of the UK's Food \& Environment Research Agency 2012 experiment.

407 PeerJ 3:e854.

408 Hall, M. R., C. J. Swanton, and G. W. Anderson. (1992) The critical period of weed 409 control in grain corn (Zea mays). Weed Science 441-447.

410 Hartwig, N.L., Ammon, H.U., 2002. Cover crops and living mulches. Weed science $41150,688-699$

412 Haughton, A., Champion, G., Hawes, C., Heard, M., Brooks, D., Bohan, D., Clark, S., 413 Dewar, A., Firbank, L., Osborne, J. (2003) Invertebrate responses to the 414 management of genetically modified herbicide-tolerant and conventional spring crops. II. Within-field epigeal and aerial arthropods. Philosophical Transactions of the Royal Society B: Biological Sciences 358, 1863-1877. 
Hawes, C., A. J. Haughton, D. A. Bohan, and Squire. G. R. (2009) Functional approaches for assessing plant and invertebrate abundance patterns in arable systems. Basic and Applied Ecology 10:34-42.

Hegland, S.J., Totland, Ø., 2005. Relationships between species' floral traits and pollinator visitation in a temperate grassland. Oecologia 145, 586-594.

Hilderbrand, R.H., Watts, A.C., Randle, A.M., 2005. The myths of restoration ecology. Ecology and Society 10, 19.

Højsgaard, S. (2006) The doBy package. The Newsletter of the R Project 6:1.

Holzschuh, A., Steffan-Dewenter, I., Kleijn, D., Tscharntke, T. (2007) Diversity of

426 flower-visiting bees in cereal fields: effects of farming system, landscape

427 composition and regional context. Journal of Applied Ecology 44, 41-49.

Liedgens, M., Soldati, A., Stamp, P., 2004. Interactions of maize and Italian ryegrass in a living mulch system: Shoot growth and rooting patterns. Plant and Soil 262, 191-203.

Manevski, K., Børgesen, C.D., Andersen, M.N., Kristensen, I.S., 2015. Reduced nitrogen leaching by intercropping maize with red fescue on sandy soils in North Europe: a combined field and modeling study. Plant and Soil 388, 67-85.

Morales, M. (2011) Sciplot: Scientific graphing functions for factorial designs. R package version: 1.0-9.

Nakamoto, T., Tsukamoto, M. (2006). Abundance and activity of soil organisms in 437 fields of maize grown with a white clover living mulch. Agriculture, Ecosystems \& Environment 115, 34-42.

Norris, S.L., Blackshaw, R.P., Dunn, R.M., Critchley, N.R., Smith, K.E., Williams, 
arthropod biodiversity in maize cultivation systems. Applied Soil Ecology 108, 2546.

Oksanen, J., Kindt, R., Legendre, P., O'Hara, B., Stevens, M.H.H., Oksanen, M.J., Suggests, M. (2007) The vegan package. Community ecology package, 631-637.

Palmer, M.A., Ambrose, R.F., Poff, N.L., 1997. Ecological Theory and Community Restoration Ecology. Restoration Ecology 5, 291-300.

Pollard, E. \& Yates, T. J. (1993) Monitoring butterflies for ecology and conservation. London: Chapman \& Hall.

Potts, S.G., Petanidou, T., Roberts, S., O'Toole, C., Hulbert, A., Willmer, P., 2006. Plant-pollinator biodiversity and pollination services in a complex Mediterranean landscape. Biological conservation 129, 519-529.

452

Prys-Jones, O. E. \& Corbet, S. A. (1991) Bumblebees, 2nd edn. Slough, UK:

Richmond Publishing Company.

Pywell, R.F., Warman, E.A., Carvell, C., Sparks, T.H., Dicks, L.V., Bennett, D.,

Wright, A., Critchley, C.N.R., Sherwood, A., 2005. Providing foraging resources for bumblebees in intensively farmed landscapes. Biological Conservation 121, 479494.

R Core Team (2013). R: A language and environment for statistical computing. R Foundation for Statistical Computing, Vienna, Austria. ISBN 3-900051-07-0, URL http://www.R-project.org/.

461 Roy, D.B., Bohan, D.A., Haughton, A.J., Hill, M.O., Osborne, J.L., Clark, S.J., Perry, 462 J.N., Rothery, P., Scott, R.J., Brooks, D.R., Champion, G.T., Hawes, C., Heard, M.S., Firbank, L.G. (2003) Invertebrates and vegetation of field margins adjacent to crops subject to contrasting herbicide regimes in the Farm Scale Evaluations of 
genetically modified herbicide-tolerant crops. Philosophical Transactions of the Royal Society of London B: Biological Sciences 358, 1879-1898.

Schlinkert, H., Westphal, C., Clough, Y., László, Z., Ludwig, M., Tscharntke, T. (2015) Plant Size as Determinant of Species Richness of Herbivores, Natural Enemies and Pollinators across 21 Brassicaceae Species. PLoS One 10, e0135928.

Tsiafouli, M.A., Thébault, E., Sgardelis, S.P., Ruiter, P.C., Putten, W.H., Birkhofer, K., Hemerik, L., Vries, F.T., Bardgett, R.D., Brady, M.V., 2015. Intensive agriculture reduces soil biodiversity across Europe. Global change biology 21, 973-985.

Westphal, C., Bommarco, R., Carré, G., Lamborn, E., Morison, N., Petanidou, T., Potts, S.G., Roberts, S.P., Szentgyörgyi, H., Tscheulin, T. (2008) Measuring bee diversity in different European habitats and biogeographical regions. Ecolological Monographs 78, 653-671.

Wilson, J.D., Morris, A.J., Arroyo, B.E., Clark, S.C., Bradbury, R.B. (1999) A review 479 of the abundance and diversity of invertebrate and plant foods of granivorous birds 480 in northern Europe in relation to agricultural change. Agriculture, Ecosystems \& Environment 75, 13-30.

Wodika, B.R., Baer, S.G. (2015). If we build it, will they colonize? A test of the field of dreams paradigm with soil macroinvertebrate communities. Applied Soil Ecology 91, 80-89.

Abbreviations

487

Conventional plough-based maize cultivation $(\mathrm{PGH})$, minimum tillage maize cultivation (MNT), strip tillage into a biodiverse seed mix ground cover (BSM), strip 
489 tillage into a perennial ryegrass ground cover (RGS), Non-metric multidimensional 490 scaling (NMDS). 